\title{
Novel 6-Phenylnicotinohydrazide Derivatives: Design, Synthesis and Biological Evaluation as a Novel Class of Antitubercular and Antimicrobial Agents
}

\author{
Dalia Hussein Soliman, ${ }^{a, b}$ Wagdy Mohamed Eldehna, ${ }^{*, c}$ Hazem Ahmed Ghabbour, ${ }^{d, e}$ \\ Maha Mamdouh Kabil, ${ }^{f}$ Marwa Mostafa Abdel-Aziz, ${ }^{g}$ and Hatem Abdel-Kader Abdel-Aziz ${ }^{h}$ \\ ${ }^{a}$ Department of Pharmaceutical Chemistry, Faculty of Pharmacy, Egyptian Russian University; Badr City, Cairo, \\ 11829, Egypt: ${ }^{b}$ Pharmaceutical Chemistry Department, Faculty of Pharmacy (Girls), Al-Azhar University; Cairo \\ 11754, Egypt: ${ }^{c}$ Department of Pharmaceutical Chemistry, Faculty of Pharmacy, Kafrelsheikh University; Kafrelsheikh \\ 33516, Egypt: ${ }^{d}$ Department of Pharmaceutical Chemistry, College of Pharmacy, King Saud University; P.O. Box \\ 2457, Riyadh 11451, Saudi Arabia: ${ }^{e}$ Department of Medicinal Chemistry, Faculty of Pharmacy, Mansoura University; \\ Mansoura 35516, Egypt: ${ }^{f}$ Department of Infection Control, King Saud University Medical City; P.O. Box 11472 \\ Riyadh, Saudi Arabia: ${ }^{g}$ The Regional Center for Mycology and Biotechnology, Al-Azhar University; Cairo 11759, \\ Egypt: and ${ }^{h}$ Department of Applied Organic Chemistry, National Research Center; Dokki, Cairo 12622, Egypt. \\ Received May 1, 2017; accepted August 16, 2017
}

In our ongoing efforts to develop potent antitubercular agents based on the 6-phenylnicotinohydrazide, herein we report the design, synthesis and biological evaluation of three sets of 6-phenylnicotinohydrazide derivatives $8 \mathrm{a}-\mathrm{g}, 12$ and $16 \mathrm{a}, \mathrm{b}$. The designed compounds were synthesized and in vitro evaluated for their antitubercular activity. In addition, their antifungal and antibacterial activities were evaluated as well. The nicotinohydrazide class displayed different levels of antimicrobial activity and possessed a distinctive pattern of selectivity against the tested microorganisms. However, the 2,6-dichlorobenzylidene counterpart $8 \mathrm{~b}$ emerged as the most active one in this study, with superior antimycobacterial activity (minimum inhibitory concentration $(\mathrm{MIC})=3.90 \mu \mathrm{g} / \mathrm{mL}$ ) and potent broad-spectrum antimicrobial activities with MIC range of $0.24-1.95 \mu \mathrm{g} / \mathrm{mL}$. The structure-activity relationship for such nicotinohydrazides has been established. Further, the cytotoxicity of the most active antitubercular compounds $8 \mathrm{~b}$, $\mathrm{d}$ and $\mathrm{g}$ were tested against the normal breast cells WI-38; none of them displayed significant cytotoxic effect, thereby providing a good therapeutic index.

Key words 6-phenylnicotinohydrazide; antitubercular; antimicrobial; synthesis; cytotoxicity

Recently, the report of the $\mathrm{WHO}^{1)}$ on universal surveillance of the antimicrobial resistance disclosed that antibiotic resistance is no longer a prediction for the future; it is occurring worldwide, and is putting at risk the ability to treat the major infections in the community and hospitals. Without an urgent and coordinated action, the world is moving towards a post-antibiotic era, in which common infections and minor injuries can once again kill. ${ }^{1)}$ The increasingly rising prevalence of multi-drug resistant microbial infections in the past few decades has become a serious health care problem. ${ }^{1)}$ The antibiotic resistance crisis could be substantially attributed to the overuse and misuse of these medications, as well as a lack of new drug development by the pharmaceutical industry because of the reduced economic momentum and exigent (demanding) regulatory requirements. ${ }^{2-7)}$ In this sense, treatment of infectious diseases still remains an important and challenging health problem. There is an urgent need for the discovery of new agents with antimicrobial activity that is distinct from the well-known classes of antimicrobial agents to which many clinically relevant pathogens have become resistant. ${ }^{8,9)}$

Tuberculosis (TB) is a top infectious disease killer worldwide. In the twentieth global report on TB published by WHO in a series that started in 1997, provided evidence that in 2014, TB killed 1.5 million people (1.1 million human immunodeficiency virus (HIV)-negative and 0.4 million HIV-positive). Worldwide, 9.6 million people are estimated to have fallen ill with TB in 2014 and 12 million prevalent latent cases of
TB reported. Globally, $12 \%$ of the 9.6 million new TB cases in 2014 were HIV-positive. Moreover, in 2014, an estimated 480000 people worldwide developed multidrug-resistant TB (MDR-TB) ${ }^{10)}$ The incidence of MDR-TB, is defined as resistance to the first-line drugs isoniazid and rifampicin, while extensively drug-resistant (XDR-TB), is defined as resistance to fluoroquinolones and to at least one of the injectable secondline drugs. ${ }^{11,12)}$ The emergence of MDR and XDR strains of Mycobacterium tuberculosis renders disease control difficult.

From 2016, the goal is to end the global TB epidemic by implementing the End TB Strategy. The strategy serves as a blueprint for countries to reduce the number of TB deaths by $90 \%$ by $2030 .{ }^{13)}$ Therefore, the resurgence of this disease spurred the coordinated urge to develop novel antimycobacterial and antimicrobial agents in order to combat such resistance. Isoniazid (INH) I (Fig. 1), is one of the first-line clinically approved drugs in TB treatment. ${ }^{14-18)}$ It was also considered as a starting point in the search for new active analogues such as hydrazones, which could be considered as an important pharmacophore for the antibacterial activities, such as Nifuroxazide $\mathbf{I I}^{19-21)}$ (Fig. 1), and also for antitubercular activities. ${ }^{22-25)}$ Additionally, some antitubercular drugs such as Phtivazid III, Verazide IV, Salinazide V and Opiniazide VI are isonicotinic acid hydrazones ${ }^{24-26)}$ (Fig. 1). Moreover, numerous studies pinpointed the importance of this scaffold for the development of unprecedented anti-TB agent. ${ }^{17,27-29)}$

The present study is a part of our ongoing efforts towards

* To whom correspondence should be addressed. e-mail: wagdy2000@gmail.com 


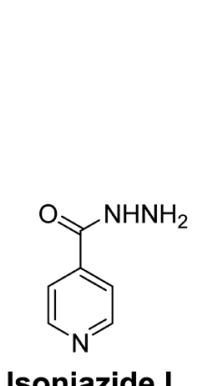

Isoniazide I

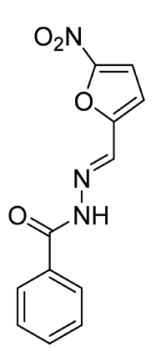

Nifuroxazide II

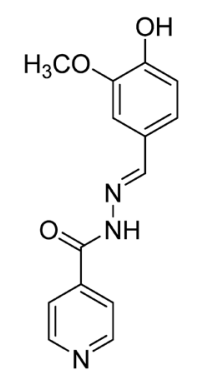

Phtivazide III<smiles>COc1ccc(/C=N/NC(=O)c2ccncc2)cc1OC</smiles>

Verazide IV

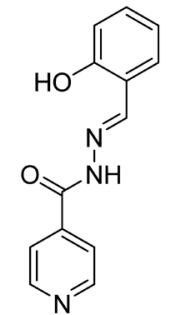

Salinazide V<smiles>COc1ccc(/C=N/NC(=O)c2ccncc2)c(C(=O)O)c1OC</smiles>

Opiniazide VI<smiles>[R]c1ccc(/C=N/NC(=O)c2ccc(-c3ccc(Br)cc3)nc2C)cc1</smiles><smiles>Cc1nc(-c2ccc(Br)cc2)ccc1C(=O)N/N=C/[Al]</smiles><smiles>Cc1nc(-c2ccc(Br)cc2)ccc1C(=O)N/N=C/c1cc(Br)ccc1OCC(=O)c1ccc(Cl)cc1</smiles><smiles></smiles>

Fig. 1. Structures of Antitubercular Agents I-VI, and the Target Compounds (8a-g, 12 and 16a, b)

developing potent antimycobacterial agents, ${ }^{30-32)}$ by the utilization of the 6-phenylnicotinohydrazide scaffold. In a previous study ${ }^{30}$ we developed seven hydrazones based on the 6-phenylnicotinohydrazide scaffold as potential antitubercular agents. The structure-activity relationship (SAR) study showed that grafting large lipophilic groups on the pendant phenyl ring as 2,4-dichloro substitution, compound 8a, could achieve an antimycobacterial activity. Motivated by this finding, we aimed to synthesis three different sets of 6-phenylnicotinohydrazide derivatives $\mathbf{8 a}-\mathbf{g}, 12$ and 16a, b (Fig. 1), with the prime goal of developing more potent and safe antimycobacterial agents and also screening their antifungal and antibacterial activities.

Four distinctive strategies were adopted to develop such derivatives. The first one focused on the usage of different substituents (disubstitution) on the pendant phenyl ring, compounds $\mathbf{8 b}-\mathbf{e}$, to ensure different lipophilic and electronic environments which may manipulate the activities of the target derivatives. In the second strategy, an extension approach was applied for compound 8e with the large lipophilic 4-chlorophenyl moiety through ketomethylene $\left(-\mathrm{CH}_{2}-\mathrm{CO}-\right)$ linker, compound 12, to achieve possible additional binding interactions. The third strategy depends on the usage of the hydrophobic alicyclic secondary amines; morpholine or piperidine as in compounds $\mathbf{1 6} \mathbf{a}$ and $\mathbf{b}$, respectively. Finally, a bioisosteric tactic was utilized to replace the pendant substituted phenyl ring in compounds 8a-e with 2-thiazolyl moiety or 3-pyridyl moiety, compounds $\mathbf{8 f}$ and $\mathbf{g}$, respectively, to carry out further elaboration of the 6-phenylnicotinohydrazide scaffold and to investigate a valuable SAR.

It is noteworthy that no attention was paid to explore the antibacterial and antifungal activities for the 6-phenylnicotinohydrazide scaffold, so far. Therefore, the synthesized derivatives $8 \mathbf{a}-\mathbf{g}, \mathbf{1 2}$ and 16a, b not only were evaluated for their anti-tubercular activity, but also assessed for their antibacterial and antifungal activities. Also, the cytotoxicity of the most active molecules was tested against the normal breast cells WI-38.

\section{RESULTS AND DISCUSSION}

Discussion of Chemistry The synthetic strategy for preparing the target nicotinic acid hydrazides $\mathbf{8 a}-\mathbf{g}, \mathbf{1 2}$ and 16a, b was illustrated in Charts 1-3. In Chart 1, synthesis of target hydrazides required three successive reactions. The enaminone $\mathbf{3}$ reacted with ethyl acetoacetate $\mathbf{4}$ and ammonium acetate in hot glacial acetic acid, to furnish the ethyl 6-(4-bromophenyl)-2-methylnicotinate $\mathbf{5}$ in a three-component heterocyclocondensation process. This was followed by hydrazinolysis of the later ester $\mathbf{5}$ to yield the nicotinic acid hydrazide $\mathbf{6}$, in $90 \%$ yield. Condensation of the hydrazide 6 with different aldehydes $7 \mathbf{a}-\mathbf{g}$, in ethyl alcohol in the presence of a catalytic amount of acetic acid furnished the target compounds $\mathbf{8 a}-\mathbf{g}$ (Chart 1).

IR spectra of compounds $\mathbf{8 a}-\mathbf{g}$ revealed the appearance of bands around 1660 and $3170 \mathrm{~cm}^{-1}$ assigned to the carbonyl and NH groups, respectively. Also, ${ }^{1} \mathrm{H}-\mathrm{NMR}$ spectra of $\mathbf{8 a}-\mathbf{g}$ displayed a singlet $\mathrm{D}_{2} \mathrm{O}$-exchangeable signal attributable to $\mathrm{NH}$ proton of hydrazine function $(=\mathrm{N}-\mathrm{NH}-)$ around $\delta 12 \mathrm{ppm}$, while the methyl $\left(-\mathrm{CH}_{3}\right)$ and methine $(-\mathrm{CH}=\mathrm{N}-)$ protons appeared around $\delta 2.60$ and $8.40 \mathrm{ppm}$, respectively, as singlet signals. Also, additional singlet signals corresponding to methoxy protons resonating around $\delta 3.70 \mathrm{ppm}$ in case of $\mathbf{8 c}$ and d were observed. Furthermore, ${ }^{13} \mathrm{C}-\mathrm{NMR}$ showed the characteristic signals for the carbons of carbonyl groups around $\delta 170.30 \mathrm{ppm}$, whereas the carbons for the methyl groups ap- 
<smiles>COC(OC)N(C)OC(=O)N(C)C</smiles>

1<smiles>Cc1nc(-c2ccc(Br)cc2)ccc1C(=O)N/N=C/[Te]</smiles>

\begin{tabular}{c|l|l}
$\mathbf{7 , 8}$ & \multicolumn{1}{|c|}{$\mathbf{A r}$} & Yield \\
\hline $\mathbf{a}$ & $2,4-\left(\mathrm{Cl}_{2}\right)-\mathrm{C}_{6} \mathrm{H}_{3^{-}}$ & $70 \%$ \\
$\mathbf{b}$ & $2,6-\left(\mathrm{Cl}_{2}\right)-\mathrm{C}_{6} \mathrm{H}_{3^{-}}$ & $73 \%$ \\
$\mathbf{c}$ & $3,4-\left(\mathrm{OCH}_{3}\right)_{2}-\mathrm{C}_{6} \mathrm{H}_{3^{-}}$ & $83 \%$ \\
$\mathbf{d}$ & $2,5-\left(\mathrm{OCH}_{3}\right)_{2}-\mathrm{C}_{6} \mathrm{H}_{3}$ & $80 \%$ \\
$\mathbf{e}$ & $5-\mathrm{Br}-2-\mathrm{OH}_{3}-\mathrm{C}_{6} \mathrm{H}_{3-}$ & $70 \%$ \\
$\mathbf{f}$ & thiophen-2-yl & $78 \%$ \\
g & pyridin-3-yl & $80 \%$
\end{tabular}

Reagents and conditions: i, xylene, reflux $8 \mathrm{~h}$; ii, $\mathrm{NH}_{4} \mathrm{OAc} / \mathrm{AcOH} / \mathrm{reflux} 5 \mathrm{~h}\left(86 \%\right.$ yield); iii, $\mathrm{NH}_{2} \mathrm{NH}_{2} \cdot \mathrm{H}_{2} \mathrm{O} / \mathrm{reflux} 3 \mathrm{~h}(90 \%$ yield); iv, EtOH/AcOH (catalytic)/reflux $4 \mathrm{~h}$ (65-83\% yield).<smiles>O=Cc1cc(Br)ccc1O</smiles>

9

Reagents and conditions: i, DMF, $\mathrm{K}_{2} \mathrm{CO}_{3}$, r.t. $1 \mathrm{~h}$ (55\% Yield); ii, EtOH/AcOH (catalytic)/reflux 4h (64\% yield).

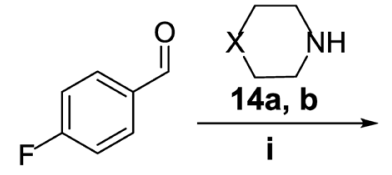

13<smiles>CN(C)/C=C/C(=O)c1ccc(Br)cc1</smiles><smiles>C=CC(C(C)=O)C(=O)OCC</smiles><smiles>CCOC(=O)c1ccc(-c2ccc(Br)cc2)nc1C(C)(N)C(C)(N)C(=O)c1ccc(-c2ccc(Br)cc2)nc1C</smiles>

iii $\mathrm{NH}_{2} \mathrm{NH}_{2} \mathrm{H}_{2} \mathrm{O}$

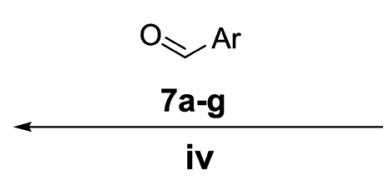<smiles>CCOC(=O)c1ccc(-c2ccc(Br)cc2)nc1C(C)(N)C(C)(N)C(=O)c1ccc(-c2ccc(Br)cc2)nc1C</smiles>

Chart 1<smiles>Cc1ccc(C(=O)CBr)cc1</smiles>

10<smiles>C1CCCC1</smiles><smiles>O=Cc1cc(Br)ccc1OCC(=O)c1ccc(Cl)cc1</smiles>

11

$$
\text { ii } \mid 6
$$<smiles>Cc1nc(-c2ccc(Br)cc2)ccc1C(=O)N/N=C/c1cc(Br)ccc1OCC(=O)c1ccc(Cl)cc1</smiles>

Chart 2<smiles>O=Cc1ccc(N2CCCCC2)cc1</smiles>

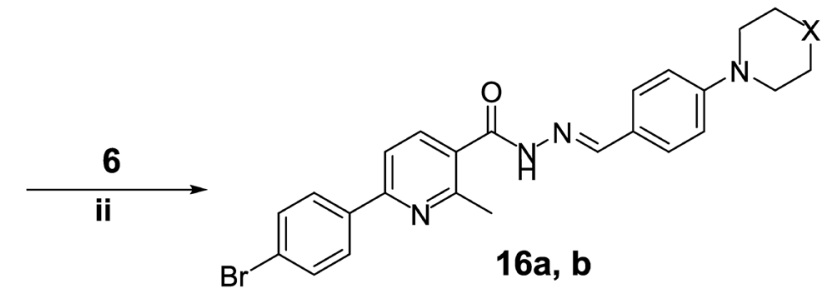

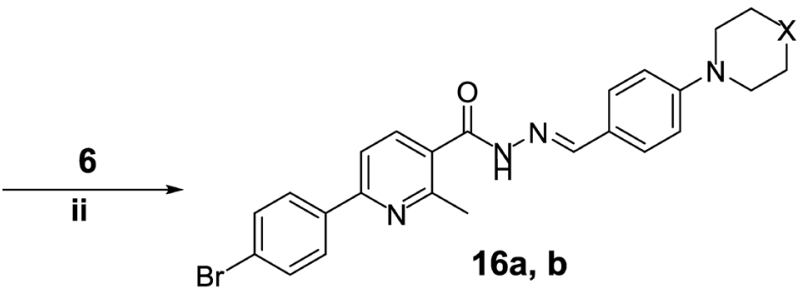

14,15,16; $\mathbf{a}: \mathrm{X}=\mathrm{O}, \mathbf{b}: \mathrm{X}=\mathrm{CH}_{2}$ 
peared around $\delta 23.40 \mathrm{ppm}$.

On the other hand, $O$-alkylation of 5-bromo-2-hydroxybenzaldehyde 9 with 2-bromo-1-(4-chlorophenyl)ethanone $\mathbf{1 0}$ in dry $N, N$-dimethylformamide (DMF) in presence of potassium carbonate yielded aldehyde derivative 11. The latter was heated under reflux with hydrazide $\mathbf{6}$ in absolute ethyl alcohol and catalytic amount of glacial acetic acid to afford the target derivative 12 (Chart 2).

IR spectrum of $\mathbf{1 2}$ confirmed the presence of two peaks at 1701 and $3155 \mathrm{~cm}^{-1}$ corresponding to the $(\mathrm{C}=\mathrm{O})$ and $\mathrm{NH}$ groups, respectively. The ${ }^{1} \mathrm{H}-\mathrm{NMR}$ spectrum of $\mathbf{1 2}$ showed two singlet signals of the aliphatic $\left(-\mathrm{OCH}_{2}-\right)$ and methine $(-\mathrm{CH}=\mathrm{N}-)$ protons at $\delta 5.72$ and $8.00 \mathrm{ppm}$, respectively, also, ${ }^{1} \mathrm{H}-\mathrm{NMR}$ spectrum revealed the presence of $\mathrm{D}_{2} \mathrm{O}$ exchangable $\mathrm{NH}$ proton at a $\delta 12.14 \mathrm{ppm}$.

Finally, $p$-flourobenzaldehyde $\mathbf{1 3}$ was reacted with an appropriate alicyclic secondary amine 14a, b in dry dimethyl sulfoxide (DMSO) in presence of potassium carbonate to furnish aldehydes 15a, b (yield, 65 and 70\%, respectively), which condensed with hydrazide $\mathbf{6}$ in absolute ethyl alcohol and catalytic amount of glacial acetic acid to afford the respective target derivative 16a, b in good yield (Chart 3).

${ }^{1} \mathrm{H}-\mathrm{NMR}$ spectra for the latter products showed singlet $\mathrm{D}_{2} \mathrm{O}$-exchangeable signals attributable to $\mathrm{NH}$ proton of the hydrazine function $(=\mathrm{N}-\mathrm{NH}-)$ around $\delta 11.70 \mathrm{ppm}$, while the methyl $\left(-\mathrm{CH}_{3}\right)$ protons appeared at $\delta 2.65 \mathrm{ppm}$ as singlet signals. Also, their ${ }^{1} \mathrm{H}-\mathrm{NMR}$ revealed the protons of morpholine and piperidine moiety in the aliphatic regions; $(\delta 1.53-1.59$ and $3.19 \mathrm{ppm}$ for piperidine moiety) and ( $\delta 3.11$ and $3.367 \mathrm{ppm}$ for morpholine moiety moiety).

The prepared hydrazones in this study appeared in the ${ }^{1} \mathrm{H}-\mathrm{NMR}$ spectra (in the solution state, DMSO- $d_{6}$ ) as mixed $E$ and $Z$ geometrical isomers due to the imine $\mathrm{C}=\mathrm{N}$ double bond. While, the X-ray single crystal analysis for compound 8 a illustrates the interesting property of such hydrazone in the crystalline state as an $E$ geometrical isomer around $(\mathrm{C}=\mathrm{N})$ (Supplementary Materials). ${ }^{33-35)}$

\section{Discussion of Biological Evaluation}

Anti-microbial Activity

Antimycobacterial, antifungal and antibacterial activities for the target compounds $\mathbf{8 a}-\mathbf{g}, \mathbf{1 2}, \mathbf{1 6} \mathbf{a}, \mathbf{b}$ and reference drugs were in vitro evaluated at the Regional Center for Mycology and Biotechnology (RCMB), Al-Azhar University, Cairo, Egypt. The results are represented in Tables 1-3.

Antimycobacterial Activity

Target compounds $\mathbf{8 a}-\mathbf{g}, \mathbf{1 2}, \mathbf{1 6 a}, \mathbf{b}$ were in vitro evaluated for their antitubercular activity against $M$. tuberculosis (RCMB 010126) using the microplate Alamar blue assay $(\mathrm{MABA}){ }^{36)}$ Isoniazide and pyrazinamide were used as reference drugs. The results of the in vitro antimycobacterial screening, as percent inhibition and minimum inhibitory concentration (MIC), are summarized in Table 1. Among the tested hydrazones, compound $\mathbf{8 b}$ emerged as the most potent member with significant antimycobacterial activity with a MIC value of $3.9 \mu \mathrm{g} / \mathrm{mL}$. Compound $\mathbf{8 g}$ also exhibited moderate activity $(\mathrm{MIC}=15.63 \mu \mathrm{g} / \mathrm{mL})$. Otherwise, compounds $\mathbf{8 c}$, $\mathbf{8 d}$ and $\mathbf{1 2}$ possessed modest anti-tubercular activity with MIC values range of: 62.5 to $125 \mu \mathrm{g} / \mathrm{mL}$.

Upon examining the MIC results in Table 1, worthy information about the structure activity relationships, of compounds $8 \mathbf{a}-\mathbf{g}, \mathbf{1 2}, \mathbf{1 6} \mathbf{a}, \mathbf{b}$ with respect to their antitubercular activity, could be concluded. Firstly, we examined the effect of grafting different two substituents on the pendent phenyl ring on the prepared hydrazones activity. Incorporation of two lipophilic groups as chloro or methoxy groups led to compounds $\mathbf{8 b}-\mathbf{d}$ with potent to modest activity (MIC: $3.90-100 \mu \mathrm{g} / \mathrm{mL})$. Conversely, introduction of hydrophilic group $(-\mathrm{OH})$ and lipophilic one $(-\mathrm{Br})$, as in compound $\mathbf{8 e}$, abolished the activity. Also, appending alicyclic secondary amines; morpholine or piperidine as in compounds $\mathbf{1 6 \mathbf { a }}$ and b, diminished the activity, suggesting that substitution of the pendant phenyl group with two lipophilic groups is crucial for the antimycobacterial activity.

On the other hand, the positional isomerism; moving the two chlorine atoms from 2,4 positions in compound $\mathbf{8 a}$ to 2,6 positions in $\mathbf{8 b}$, resulted in about 25 fold increase in the antimycobacterial activity, hinting that the positions of such two lipophilic groups greatly affect the activity. The order of activity of the disubstituted hydrazones $\mathbf{8 a}-\mathbf{d}$ was 2,6-dichloro $\mathbf{8 b}>3,4$-dimethoxy $\mathbf{8 c}>2,4$-dichloro $\mathbf{8 a}$ and 2,5-dimethoxy $\mathbf{8 d}$ $(\mathrm{MIC}=3.90,62.5,100$ and $100 \mu \mathrm{g} / \mathrm{mL}$, respectively). Moreover, extending compound $8 \mathbf{e}(\mathrm{MIC}=>150 \mu \mathrm{g} / \mathrm{mL})$ with the large lipophilic 4-chlorophenyl moiety through ketomethylene $\left(-\mathrm{CH}_{2}-\mathrm{CO}-\right)$ linker, led to a comparatively active counterpart $12(\mathrm{MIC}=125 \mu \mathrm{g} / \mathrm{mL})$, confirming that presence of hydrophilic group is not favorable for activity.

Finally, we examined the effect of bioisosteric replacement of the pendant substituted phenyl moiety in compounds 8a-d. Interestingly, attaching 3-pyridyl group, compound $\mathbf{8 g}$, as bioisostere to the phenyl one maintained the activity ( $\mathrm{MIC}=62.5 \mu \mathrm{g} / \mathrm{mL}$ ), while 2-thienyl group, 8f, abolished the activity.

\section{Anti-fungal Activity}

Target compounds $\mathbf{8 a}-\mathbf{g}, \mathbf{1 2}, \mathbf{1 6} \mathbf{a}, \mathbf{b}$ and amphotericin, a membrane-active polyene macrolide antibiotic and an antifungal reference drug, were in vitro evaluated for their antifungal activity, by inhibition zone (I.Z.) technique and MIC, ${ }^{32)}$ towards Aspergillus fumigatus and Candida albicans, Table 2.

Aspergillus species, globally ubiquitous saprophytes, are found in a variety of ecological niches. More than 200 species of aspergilli have been identified, less than 20 of which are recognized to cause human disease. Among them, A. fumigatus was found to be the most prevalent and is predominantly responsible for the increased incidence of invasive aspergillosis in the immunocompromised patient.

As for the antifungal activity, data in Table 2 showed that the 2,5-dimethoxybenzylidene derivative $8 \mathbf{d}$ demonstrated the best activity amongst the tested compounds against $A$. fumigatus $(\mathrm{MIC}=0.49 \mu \mathrm{g} / \mathrm{mL}$ ), which was 2-fold more potent than the reference dug, amphotericin $(\mathrm{MIC}=0.98 \mu \mathrm{g} / \mathrm{mL})$. While, compounds $\mathbf{8 b}$ and $\mathbf{g}$ were equipotent to amphotericin against A. fumigatus. Furthermore, derivatives 8a, c, f, 12 and 16b showed moderate activity against $A$. fumigatus $(\mathrm{MIC}=7.81$, $1.95,7.81,3.9$ and $15.63 \mu \mathrm{g} / \mathrm{mL}$, respectively)

Regarding the activity against Candida albicans, the 2,6-dichlorobenzylidene counterpart $\mathbf{8 b}$ was the most active one with $\mathrm{MIC}=0.98 \mu \mathrm{g} / \mathrm{mL}$. Also, compound 8d displayed good activity and was equipotent to amphotericin against Candida albicans, $(\mathrm{MIC}=1.95 \mu \mathrm{g} / \mathrm{mL})$. Moreover, compounds 8a, c, f, g, 12 and 16b were moderately active, against Candida albicans, with MIC values ranging from 3.9 to $31.25 \mu \mathrm{g} / \mathrm{mL}$. 
Table 1. Structures, Antitubercular Activities, $\log P$ Measurements and Drug-Likeness Model Score of the Synthesized Derivatives

\begin{tabular}{|c|c|c|c|c|c|}
\hline Compound & Structure & $\begin{array}{l}\text { Mean of } \\
\text { inhibition \% }\end{array}$ & $\begin{array}{l}\text { MIC } \\
(\mu \mathrm{g} / \mathrm{ml})\end{array}$ & $\log P^{\mathrm{a}}$ & $\begin{array}{l}\text { Drug-likeness } \\
\text { model score }\end{array}$ \\
\hline $8 a$ & & $13.57 \pm 0.72$ & 100 & 6.23 & 0.13 \\
\hline $8 b$ & & $79.21 \pm 3.51$ & 3.90 & 6.21 & 0.35 \\
\hline $8 c$ & & $52.14 \pm 2.28$ & 62.5 & 4.60 & 0.66 \\
\hline $8 d$ & & $27.33 \pm 1.50$ & 100 & 4.99 & 0.07 \\
\hline $8 e$ & & NA & NA & 5.67 & 0.47 \\
\hline $8 f$ & & NA & NA & 4.85 & 0.20 \\
\hline $8 g$ & & $67.28 \pm 0.58$ & 15.63 & 3.71 & 0.78 \\
\hline 12 & & $22.43 \pm 1.59$ & 125 & 7.57 & 0.36 \\
\hline $16 a$ & & NA & NA & 4.90 & 0.20 \\
\hline $16 \mathrm{~b}$ & & NA & NA & 5.96 & -0.09 \\
\hline Pyrazinamid & & $93.25 \pm 1.63$ & 3.21 & & \\
\hline INH & & $83.2 \pm 2.16$ & 3.90 & & \\
\hline
\end{tabular}

a: Calculated by [www.molinspiration.com]; b: Calculated by ref. 48; NA: No activity ( $>150 \mu \mathrm{g} / \mathrm{mL})$.

\section{Antibacterial Activity}

The results in Table 3 showed that the compound $\mathbf{8 b}$ demonstrated broad and excellent activity among all the tested compounds, it was twice the activity of ampicillin against Staphylococcus aureus and Bacillus subtilis (0.49, $0.24 \mu \mathrm{g} / \mathrm{mL}$, ampicillin, $0.98,0.49 \mu \mathrm{g} / \mathrm{mL}$ ), it was also equipotent to Gentamicin against Salmonella typhimurium, Klebsi- ella penumoniae and Escherichia coli $(0.98,0.49,0.49 \mu \mathrm{g} / \mathrm{mL})$. The (2,4-dichlorobenzylidene)-2-methylnicotinohydrazide $\mathbf{8 a}$ was equipotent to ampicillin against $S$. aureus, $(0.98 \mu \mathrm{g} / \mathrm{mL})$, it also possessed the same activity against Streptococus pneumoniae and B. subtilis as ciprofloxacin $(1.95 \mu \mathrm{g} / \mathrm{mL})$. As for the Gram-negative ( $\mathrm{g}-\mathrm{ve}$ ) activity, it exhibited 4-foldsthe activity of ciprofloxacin against $K$. penumoniae and possessed 
Table 2. Antifungal Activity of the Tested Standards and Synthesized Compounds; Expressed as Inhibition Diameter Zones (I.Z.) in mm, and Minimum Inhibitory Concentrations (MIC) in $\mu \mathrm{g} / \mathrm{mL}$<smiles>[R]c1ccc(/C=N/NC(=O)c2ccc(-c3ccc(Br)cc3)nc2C)cc1</smiles><smiles></smiles><smiles>Cc1nc(-c2ccc(Br)cc2)ccc1C(=O)N/N=C/c1cc(Br)ccc1OCC(=O)c1ccc(Cl)cc1</smiles><smiles>Cc1nc(-c2ccc(Br)cc2)ccc1C(=O)N/N=C/c1ccc(N2CCCCC2)cc1</smiles>

\begin{tabular}{|c|c|c|c|c|c|}
\hline \multirow{2}{*}{ Compound } & \multirow{2}{*}{$\mathrm{R} / \mathrm{Ar} / \mathrm{X}$} & \multicolumn{2}{|c|}{ I.Z. (mm) } & \multicolumn{2}{|c|}{$\mathrm{MIC}(\mu \mathrm{g} / \mathrm{mL})$} \\
\hline & & Af & $\mathrm{Ca}$ & Af & $\mathrm{Ca}$ \\
\hline $8 a$ & $2,4-\left(\mathrm{Cl}_{2}\right)-\mathrm{C}_{6} \mathrm{H}_{3}-$ & $18.2 \pm 0.38$ & $17.3 \pm 0.58$ & 7.81 & 15.63 \\
\hline $8 b$ & $2,6-\left(\mathrm{Cl}_{2}\right)-\mathrm{C}_{6} \mathrm{H}_{3}-$ & $23.4 \pm 0.25$ & $24.1 \pm 1.5$ & 0.98 & 0.98 \\
\hline $8 \mathrm{c}$ & $3,4-\left(\mathrm{OCH}_{3}\right)_{2}-\mathrm{C}_{6} \mathrm{H}_{3}-$ & $21.2 \pm 0.58$ & $18.3 \pm 0.58$ & 1.95 & 7.81 \\
\hline $8 d$ & $2,5-\left(\mathrm{OCH}_{3}\right)_{2}-\mathrm{C}_{6} \mathrm{H}_{3}-$ & $24.7 \pm 0.38$ & $20.8 \pm 1.2$ & 0.49 & 1.95 \\
\hline $8 e$ & $5-\mathrm{Br}-2-\mathrm{OH}-\mathrm{C}_{6} \mathrm{H}_{3}-$ & $20.1 \pm 0.63$ & $18.3 \pm 0.58$ & 62.5 & 125 \\
\hline $8 f$ & Thiophen-2-yl & $18.2 \pm 0.58$ & $15.4 \pm 0.34$ & 7.81 & 31.25 \\
\hline $8 g$ & Pyridin-3-yl & $22.9 \pm 0.25$ & $19.3 \pm 1.53$ & 0.98 & 3.9 \\
\hline 12 & - & $13.6 \pm 0.37$ & $11.4 \pm 1.20$ & 3.9 & 7.81 \\
\hline $16 \mathrm{a}$ & $\mathrm{O}$ & $14.2 \pm 0.25$ & $13.6 \pm 1.25$ & 62.5 & 62.5 \\
\hline $16 b$ & $\mathrm{CH}_{2}$ & $16.9 \pm 0.58$ & $16.4 \pm 1.33$ & 15.63 & 31.25 \\
\hline $\mathrm{AB}$ & & $23.1 \pm 0.90$ & $21.3 \pm 0.72$ & 0.98 & 1.95 \\
\hline
\end{tabular}

The screening organisms, Aspergillus fumigatus (RCMB 02568, Af), Candida albicans (RCMB 05036, Ca), AB: Amphotericin B.

Table 3. Antibacterial Activity of the Tested Standards and Synthesized Compounds; Expressed as Inhibition Diameter Zones (I.Z.) in mm, and Minimum Inhibitory Concentrations (MIC) in $\mu \mathrm{g} / \mathrm{mL}$

\begin{tabular}{|c|c|c|c|c|c|c|c|c|c|c|c|c|c|c|}
\hline \multirow{3}{*}{ Comp. } & \multicolumn{6}{|c|}{ Gram-positive bacteria } & \multicolumn{8}{|c|}{ Gram-negative bacteria } \\
\hline & \multicolumn{3}{|c|}{ I.Z. (mm) } & \multicolumn{3}{|c|}{$\operatorname{MIC}(\mu \mathrm{g} / \mathrm{mL})$} & \multicolumn{4}{|c|}{ I.Z. (mm) } & \multicolumn{4}{|c|}{$\operatorname{MIC}(\mu \mathrm{g} / \mathrm{mL})$} \\
\hline & $\mathrm{Sa}$ & $\mathrm{Sp}$ & Bs & $\mathrm{Sa}$ & $\mathrm{Sp}$ & Bs & $\mathrm{Pa}$ & $\mathrm{St}$ & $\mathrm{Kp}$ & $\mathrm{Ec}$ & $\mathrm{Pa}$ & $\mathrm{St}$ & $\mathrm{Kp}$ & $\mathrm{Ec}$ \\
\hline $8 \mathbf{a}$ & 22.4 & 21.3 & 20.6 & 0.98 & 1.95 & 1.95 & 18.3 & 21.3 & 22.4 & 22.6 & 7.81 & 1.95 & 0.98 & 0.98 \\
\hline $8 b$ & 25.2 & 24.1 & 26.4 & 0.49 & 0.49 & 0.24 & 21.3 & 22.7 & 25.4 & 26.3 & 1.95 & 0.98 & 0.49 & 0.49 \\
\hline $8 c$ & 21.3 & 22.1 & 20.3 & 1.95 & 0.98 & 3.9 & NA & 18.4 & 20.3 & 21.2 & NA & 7.81 & 3.9 & 1.95 \\
\hline $8 d$ & 20.4 & 22.6 & 19.8 & 3.9 & 0.98 & 3.9 & 21.3 & 23.4 & 24.9 & 26.4 & 1.95 & 0.98 & 0.49 & 0.49 \\
\hline $8 e$ & 18.7 & 21.3 & 20.2 & 7.81 & 7.81 & 31.25 & NA & 18.3 & 21.2 & 21.9 & NA & 31.25 & 15.63 & 7.81 \\
\hline $8 f$ & 13.6 & 16.4 & 12.4 & 62.5 & 31.25 & 125 & NA & 13.2 & 15.7 & 17.3 & NA & 62.5 & 31.25 & 15.63 \\
\hline $8 g$ & 24.2 & 23.6 & 21.3 & 0.49 & 0.49 & 1.95 & 19.6 & 22.4 & 24.6 & 25.1 & 3.9 & 0.98 & 0.49 & 0.49 \\
\hline 12 & 18.2 & 17.6 & 16.1 & 3.9 & 1.95 & 3.9 & NA & 15.6 & 17.1 & 17.9 & NA & 7.81 & 1.95 & 62.5 \\
\hline $16 a$ & 17.3 & 17.9 & 13.6 & 15.63 & 7.81 & 62.5 & NA & 11.2 & 13.4 & 16.2 & NA & 125 & 62.5 & 31.25 \\
\hline $16 b$ & 21.9 & 21.2 & 20.1 & 0.98 & 1.95 & 3.9 & 16.3 & 20.4 & 21.6 & 22.2 & 31.25 & 3.9 & 0.98 & 0.98 \\
\hline Ap & 26.4 & 25.3 & 28.9 & 0.98 & 0.49 & 0.49 & & & & & & & & \\
\hline GM & & & & & & & 26.3 & 23.2 & 27.5 & 27.3 & 0.98 & 0.98 & 0.49 & 0.49 \\
\hline $\mathrm{CF}$ & 22.2 & 23.3 & 25.4 & 1.95 & 1.95 & 1.95 & 23.1 & 21.8 & 24.7 & 24.3 & 3.90 & 3.90 & 3.90 & 1.95 \\
\hline
\end{tabular}

NA: No Activity. The screening organisms, Gram-positive bacteria: Staphylococcus aureus (RCMB 010028, Sa), Streptococus pneumoniae (RCMB 010010, Sp), and Bacillus subtilis (RCMB 010069, Bs). Gram-negative bacteria: Pseudomonas aeruginosa (RCMB 010043, Pa), Salmonella typhimurium (RCMB 010315, St), Klebsiella penumoniae (RCMB 0010093, Kp) and Escherichia coli (RCMB 010052, Ec), AP: Ampicillin, GM: Gentamicin, CF: Ciprofloxacin.

twice its activity against $S$. typhimurium and E. coli. On the other hand, compound $\mathbf{8 g}$ demonstrated twice the activity of ampicillin against $S$. aureus, the same potency as ampicillin against ( $S$. pneumoniae) as well as (the effect of gentamicin on) the g-ve organisms, S. typhimurium, K. penumoniae and E. coli. Furthermore, the benzylidene derivative $8 \mathbf{c}$ showed equipotent activity to ciprofloxacin against $S$. aureus, $K$. penu- moniae, E. coli and was almost 2-folds its activity against $S$. pneumoniae. Regarding the activity of piperidinylbenzylidene counterpart 16b, it exhibited g-ve and Gram-positive ( $g+v e)$ activity, it was found to demonstrate the same activity as ampicillin against $S$. aureus $(0.98 \mu \mathrm{g} / \mathrm{mL})$ and same potency as ciprofloxacin against $S$. pneumoniae $(1.95 \mu \mathrm{g} / \mathrm{mL})$. The $\mathrm{g}-\mathrm{ve}$ activity of this compound $\mathbf{1 6} \mathbf{b}$, was also demonstrated by its 


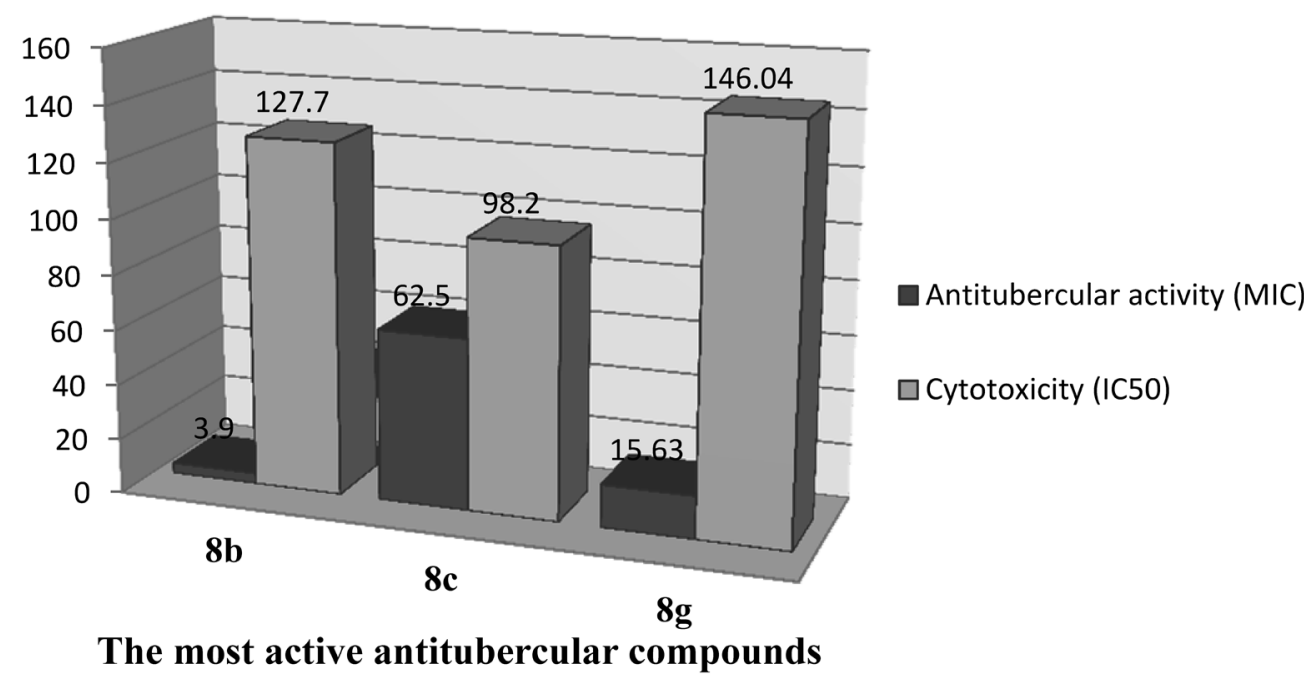

Fig. 2. Antitubercular Activity (MIC) and Cytotoxicity $\left(\mathrm{IC}_{50}\right)$ of Compounds $\mathbf{8 b}$, $\mathbf{c}$ and $\mathbf{g}$ against Normal Breast Cells WI-38

activity against $S$. typhimurium with the same potency as ciprofloxacin $(3.9 \mu \mathrm{g} / \mathrm{mL}), 4$-folds its activity against $K$. penumoniae and 2-folds the activity against E. coli. In particular, the arylidene-hydrazide derivatives $\mathbf{8 b}$, $\mathbf{d}$ and $\mathbf{g}$ were the only derivatives in this series that showed activity against the $\mathrm{g}-\mathrm{ve}$ resistant, Pseudomonas aeruginosa, where $\mathbf{8 b}$ and d were twice as potent as ciprofloxacin $(1.95$ and $3.9 \mu \mathrm{g} / \mathrm{mL})$ and $\mathbf{8 g}$ was equipotent.

\section{In vitro Cytotoxicity}

The cytotoxic activity of the most active antitubercular derivatives $\mathbf{8 b}$, $\mathbf{c}$ and $\mathbf{g}$ were tested against normal breast cells WI-38 using 3-(4,5-dimethylthiazol-2-yl)-2,5-diphenyltetrazolium bromide (MTT) assay. ${ }^{37)}$ The results are expressed as growth inhibitory concentration values $\left(\mathrm{IC}_{50}\right)$ which represent the concentration of the compound needed to make a $50 \%$ inhibition of cell growth after $48 \mathrm{~h}$ of incubation compared to untreated control. None of the three compounds displayed significant cytotoxic effect $\left(\mathrm{IC}_{50}=127.7,98.2\right.$ and $146.04 \mu \mathrm{M}$, respectively), thereby providing a good therapeutic index (Fig. 2).

\section{CONCLUSION}

In conclusion, three sets of 6-phenylnicotinohydrazide derivatives $8 \mathbf{a}-\mathbf{g}, \mathbf{1 2}$ and $\mathbf{1 6 a}, \mathbf{b}$ were designed, synthesized and tested in vitro for their activity against $M$. tuberculosis. Also, the antifungal and antibacterial activities for such compounds were evaluated. Compound $\mathbf{8 b}$ was found to be the most promising member in this study, with superior antimycobacterial activity $(\mathrm{MIC}=3.90 \mu \mathrm{g} / \mathrm{mL})$ and potent broad-spectrum antimicrobial activities with MIC range of $0.24-1.95 \mu \mathrm{g} / \mathrm{mL}$. The impact of incorporation of two large lipophilic groups, extension approach and bioisosteric replacement of the pendant phenyl moiety, was explored by the SAR study. The cytotoxicity of the most active antitubercular compounds $\mathbf{8 b}$, $\mathbf{d}$ and $\mathbf{g}$ were tested against the normal breast cells WI-38; none of them displayed significant cytotoxic effect, thereby providing a good therapeutic index. Structures of compounds $\mathbf{8 a}$ and 11 were further substantiated via X-ray single crystal analysis.

\section{MATERIALS AND METHODS}

General Chemistry Melting points were measured with a Stuart melting point apparatus and were uncorrected. IR spectra were recorded as potassium bromide discs on Shimadzu FT-IR 8400S spectrophotometer and expressed in wave number $\left(\mathrm{cm}^{-1}\right)$. The NMR spectra were recorded by Bruker spectrophotometer at $400 \mathrm{MHz}$. ${ }^{1} \mathrm{H}-\mathrm{NMR}$ spectra were run at $400 \mathrm{MHz}$, while ${ }^{13} \mathrm{C}-\mathrm{NMR}$ spectra were run at $100 \mathrm{MHz}$ in deuterated dimethylsulphoxide (DMSO- $\left.d_{6}\right)$. Chemical shifts $\left(\delta_{\mathrm{H}}\right)$ are reported relative to TMS as internal standard. All coupling constant $(J)$ values are given in hertz. Chemical shifts $\left(\delta_{\mathrm{C}}\right)$ are reported relative to DMSO- $d_{6}$ as internal standards. The abbreviations used are as follows: s, singlet; $\mathrm{d}$, doublet; m, multiplet. Mass spectra were measured on a GCMS-QP1000 EX and Helwett Packard 5988 spectrometers at $70 \mathrm{e.V}$. Elemental analyses was carried out at the Regional Center for Microbiology and Biotechnology, Al-Azhar University, Cairo, Egypt. Reaction courses and product mixtures were routinely monitored by TLC on silica gel precoated $\mathrm{F}_{254}$ Merck plates. Unless otherwise noted, all solvents and reagents were commercially available and used without further purification.

1-(4-Bromophenyl)-3-(dimethylamino)prop-2-en-1-one 3

Compound 3 was prepared according to reported procedure $^{38)}\left(\mathrm{mp} 79-80^{\circ} \mathrm{C}\right.$, reported $75-77^{\circ} \mathrm{C}^{38)}$ ).

Ethyl 6-(4-Bromophenyl)-2-methylnicotinate 5

Compound $\mathbf{5}$ was prepared according to reported procedure $^{39)}\left(\mathrm{mp} 74-75^{\circ} \mathrm{C}\right.$, reported $\left.72-74^{40)}\right)$.

6-(4-Bromophenyl)-2-methylnicotinohydrazide 6

Compound $\mathbf{6}$ was prepared according to reported procedure $^{30)}\left(\mathrm{mp} 239-241^{\circ} \mathrm{C}\right.$, as reported $\left.{ }^{30)}\right)$.

General Procedure for Preparation of $N^{\prime}$-Arylidene-6(4-bromophenyl)-2-methylnicotinohydrazides $\mathbf{8 a - g}$ The appropriate aldehyde derivative $7 \mathbf{a}-\mathbf{g}(1 \mathrm{mmol})$ was added to a solution of the 6-(4-bromophenyl)-2-methylnicotinohydrazide $6(0.31 \mathrm{~g}, 1 \mathrm{mmol})$ in absolute ethyl alcohol $(10 \mathrm{~mL})$ and a catalytic amount of glacial acetic acid. The reaction mixture was heated under reflux for $3 \mathrm{~h}$. The formed precipitate was filtered off while hot, washed with methanol, and finally crystallized from ethanol/dioxane to furnish the target compounds $\mathbf{8 a}-\mathbf{g}$ 
with $65-83 \%$ yield.

6-(4-Bromophenyl)- $N^{\prime}$-(2,4-dichlorobenzylidene)-2methylnicotinohydrazide (8a)

White crystals (yield $70 \%$ ), mp $269-271^{\circ} \mathrm{C}^{30}{ }^{30}$

6-(4-Bromophenyl)- $N^{\prime}$-(2,6-dichlorobenzylidene)-2methylnicotinohydrazide $(\mathbf{8 b})$

White crystals (yield $73 \%$ ), mp $261-263^{\circ} \mathrm{C}$; IR (KBr, $\left.v \mathrm{~cm}^{-1}\right): 3167(\mathrm{NH})$ and $1651(\mathrm{C}=\mathrm{O}) ;{ }^{1} \mathrm{H}-\mathrm{NMR}\left(\mathrm{DMSO}-d_{6}\right)$ $\delta$ ppm: 2.53, $2.65\left(2 \mathrm{~s}, 3 \mathrm{H}, \mathrm{CH}_{3}\right), 7.35-7.42(\mathrm{~m}, 3 \mathrm{H}, \mathrm{Ar}-\mathrm{H})$, $7.71(\mathrm{~d}, 2 \mathrm{H}, \mathrm{Ar}-\mathrm{H}, J=8.40 \mathrm{~Hz}), 7.85-8.00(\mathrm{~m}, 2 \mathrm{H}, \mathrm{Ar}-\mathrm{H})$, 8.09 (d, 2H, Ar-H, J=8.48 Hz), 8.34, 8.62 (2 s, 1H, Ar-H), 11.96, 12.03 ( $2 \mathrm{~s}, 1 \mathrm{H}, \mathrm{NH}, \mathrm{D}_{2} \mathrm{O}$ exchangeable); Anal. Calcd for $\mathrm{C}_{20} \mathrm{H}_{14} \mathrm{BrCl}_{2} \mathrm{~N}_{3} \mathrm{O}$ : C, 51.87; H, 3.05; N, 9.07. Found: C, 51.54; $\mathrm{H}, 3.09$; N, 9.15.

6-(4-Bromophenyl)- $N^{\prime}$-(3,4-dimethoxybenzylidene)-2methylnicotinohydrazide $(\mathbf{8 c})$

White crystals (yield $83 \%$ ), mp $233-235^{\circ} \mathrm{C}$; IR ( $\mathrm{KBr}$, $\left.v \mathrm{~cm}^{-1}\right): 3150(\mathrm{NH})$ and $1651(\mathrm{C}=\mathrm{O}) ;{ }^{1} \mathrm{H}-\mathrm{NMR}\left(\mathrm{DMSO}-d_{6}\right)$

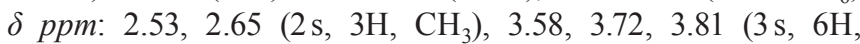
2- $\left.\mathrm{OCH}_{3}\right), 6.92-7.20(\mathrm{~m}, 2 \mathrm{H}, \mathrm{Ar}-\mathrm{H}), 7.37$ (s, 1H, Ar-H), 7.70 (d, 2H, Ar-H, J=8.44 Hz), 7.85-8.00 (m, 2H, Ar-H), 8.09 (d, $2 \mathrm{H}, \mathrm{Ar}-\mathrm{H}, J=8.52 \mathrm{~Hz}), 8.24(\mathrm{~s}, 1 \mathrm{H}, \mathrm{Ar}-\mathrm{H}), 11.80,11.91(2 \mathrm{~s}$, $1 \mathrm{H}, \mathrm{NH}, \mathrm{D}_{2} \mathrm{O}$ exchangeable); ${ }^{13} \mathrm{C}-\mathrm{NMR}$ (DMSO-d $)_{6} \delta \mathrm{ppm}$ : $23.43\left(\mathrm{CH}_{3}\right), 55.52,55.92\left(\mathrm{OCH}_{3}\right), 55.98,56.04\left(\mathrm{OCH}_{3}\right), 108.73$, $109.28,111.93,112.10,117.06,117.58,120.89,122.49,123.41$, $123.63,127.25,129.11,129.24,129.85,132.24,137.31,137.51$, $137.56,137.79,144.24,148.58,149.26,149.55,150.88,151.35$, 154.72, 155.16, 155.41, 156.40, 164.21, 170.21; Anal. Calcd for $\mathrm{C}_{22} \mathrm{H}_{20} \mathrm{BrN}_{3} \mathrm{O}_{3}: \mathrm{C}, 58.16 ; \mathrm{H}, 4.44 ; \mathrm{N}, 9.25$. Found: C, 58.34; H, 4.48; N, 9.16 .

6-(4-Bromophenyl)- $N^{\prime}$-(2,5-dimethoxybenzylidene)-2methylnicotinohydrazide (8d)

White crystals (yield $80 \%$ ), mp $235-237^{\circ} \mathrm{C}$; IR $(\mathrm{KBr}$, $\left.v \mathrm{~cm}^{-1}\right): 3170(\mathrm{NH})$ and $1662(\mathrm{C}=\mathrm{O}) ;{ }^{1} \mathrm{H}-\mathrm{NMR}\left(\mathrm{DMSO}-d_{6}\right)$ $\delta$ ppm: 2.52, $2.66\left(2 \mathrm{~s}, 3 \mathrm{H}, \mathrm{CH}_{3}\right), 3.51,3.81\left(2 \mathrm{~s}, 3 \mathrm{H}, \mathrm{OCH}_{3}\right)$, $3.77\left(\mathrm{~s}, 3 \mathrm{H}, \mathrm{OCH}_{3}\right), 6.79-7.39(\mathrm{~m}, 3 \mathrm{H}, \mathrm{Ar}-\mathrm{H}), 7.70(\mathrm{~d}, 2 \mathrm{H}$, Ar-H, $J=8.52 \mathrm{~Hz}), 7.83-8.00$ (m, 2H, Ar-H), 8.10 (d, $2 \mathrm{H}$, Ar-H, $J=8.40 \mathrm{~Hz}), 8.37,8.65(2 \mathrm{~s}, 1 \mathrm{H}, \mathrm{Ar}-\mathrm{H}), 11.90,11.96(2 \mathrm{~s}$, $1 \mathrm{H}, \mathrm{NH}, \mathrm{D}_{2} \mathrm{O}$ exchangeable); ${ }^{13} \mathrm{C}-\mathrm{NMR}$ (DMSO-d $\left.{ }_{6}\right) \delta p p m$ : 23.43, $23.50\left(\mathrm{CH}_{3}\right)$, 55.46, $55.94\left(\mathrm{OCH}_{3}\right)$, 56.64, $56.73\left(\mathrm{OCH}_{3}\right)$, $109.55,109.94,113.73,113.95,117.01,117.10,117.54,118.42$, $123.11,123.43,123.65,129.13,129.27,129.65,130.60,132.24$, $137.39,137.54,139.83,143.77,152.51,152.84,153.42,153.74$, 154.72, 155.07, 155.46, 156.56, 164.23, 170.35; Anal. Calcd for $\mathrm{C}_{22} \mathrm{H}_{20} \mathrm{BrN}_{3} \mathrm{O}_{3}: \mathrm{C}, 58.16 ; \mathrm{H}, 4.44 ; \mathrm{N}, 9.25$. Found: C, 57.82; H, $4.49 ; \mathrm{N}, 9.18$

$N^{\prime}$-(4-Bromo-2-hydroxybenzylidene)-6-(4-bromophenyl)-2methylnicotinohydrazide $(\mathbf{8 e})$

White crystals (yield $70 \%$ ), mp $241-242^{\circ} \mathrm{C}$; IR (KBr, $\left.v \mathrm{~cm}^{-1}\right): 3182(\mathrm{NH})$ and $1651(\mathrm{C}=\mathrm{O}) ;{ }^{1} \mathrm{H}-\mathrm{NMR}\left(\mathrm{DMSO}-d_{6}\right)$ $\delta$ ppm: 2.52, $2.67\left(2 \mathrm{~s}, 3 \mathrm{H}, \mathrm{CH}_{3}\right), 6.78,6.90(2 \mathrm{~d}, 1 \mathrm{H}, \mathrm{Ar}-\mathrm{H}$, $J=8.68 \& 8.76 \mathrm{~Hz}), 7.31,7.42(2 \mathrm{dd}, 1 \mathrm{H}$, Ar-H, $J=8.68$, $2.36 \mathrm{~Hz}$ ), 7.70 (d, 2H, Ar-H, $J=8.40 \mathrm{~Hz}), 7.82-7.96(\mathrm{~m}, 2 \mathrm{H}$, Ar-H), 8.01 (d, 1H, Ar-H, J=8.04 Hz), 8.09 (d, 2H, Ar-H, $J=8.44 \mathrm{~Hz}), 8.32,8.51(2 \mathrm{~s}, 1 \mathrm{H}, \mathrm{Ar}-\mathrm{H}), 10.26,11.14(2 \mathrm{~s}, 1 \mathrm{H}$, $\mathrm{OH}, \mathrm{D}_{2} \mathrm{O}$ exchangeable $), 12.09,12.20\left(2 \mathrm{~s}, 1 \mathrm{H}, \mathrm{NH}, \mathrm{D}_{2} \mathrm{O}\right.$ exchangeable); Anal. Calcd for $\mathrm{C}_{20} \mathrm{H}_{15} \mathrm{Br}_{2} \mathrm{~N}_{3} \mathrm{O}_{2}: \mathrm{C}, 49.11 ; \mathrm{H}$, 3.09; N, 8.59. Found: C, 48.83; H, 3.13; N, 8.68.

6-(4-Bromophenyl)-2-methyl- $N^{\prime}$-(thiophen-2-ylmethylene)nicotinohydrazide $\mathbf{( 8 f})$

White crystals (yield $78 \%$ ), mp $245-246^{\circ} \mathrm{C}$; IR (KBr, $\left.v \mathrm{~cm}^{-1}\right): 3170(\mathrm{NH})$ and $1658(\mathrm{C}=\mathrm{O}) ;{ }^{1} \mathrm{H}-\mathrm{NMR}$ (DMSO- $\left.d_{6}\right)$ $\delta$ ppm: 2.52, $2.65\left(2 \mathrm{~s}, 3 \mathrm{H}, \mathrm{CH}_{3}\right), 7.04,7.15(2 \mathrm{t}, 1 \mathrm{H}, \mathrm{Ar}-\mathrm{H}$, $J=4.40 \& 4.76 \mathrm{~Hz}), 7.37,7.48(2 \mathrm{~d}, 1 \mathrm{H}$, Ar-H, $J=3.00$ \& $2.64 \mathrm{~Hz}), 7.69-7.72(\mathrm{~m}, 3 \mathrm{H}, \mathrm{Ar}-\mathrm{H}), 7.81-7.98$ (m, 2H, Ar-H), 8.09 (d, 2H, Ar-H, J=8.52 Hz), 8.28, 8.53 (2 s, 1H, Ar-H), 11.87, $11.95\left(2 \mathrm{~s}, 1 \mathrm{H}, \mathrm{NH}, \mathrm{D}_{2} \mathrm{O}\right.$ exchangeable); ${ }^{13} \mathrm{C}-\mathrm{NMR}$ (DMSO-d $d_{6} \delta$ ppm: 23.45, $23.55\left(\mathrm{CH}_{3}\right), 117.12,117.58,123.46$, $123.67,128.31,128.39,129.00,129.18,129.26,129.60,129.70$, $130.25,130.93,131.73,132.25,137.35,137.53,137.60,137.69$, $139.15,139.33,139.82,143.48,154.77,155.15,155.49,156.47$, 164.21, 170.08; Anal. Calcd for $\mathrm{C}_{18} \mathrm{H}_{14} \mathrm{BrN}_{3} \mathrm{OS}$ : C, 54.01; H, 3.53 ; N, 10.50. Found: C, C, 53.82; H, 3.56; N, 10.33.

6-(4-Bromophenyl)-2-methyl- $N^{\prime}$-(pyridin-3-ylmethylene)nicotinohydrazide $(\mathbf{8 g})$

White crystals (yield $80 \%$ ), mp $247-249^{\circ} \mathrm{C}$; IR ( $\mathrm{KBr}$, $\left.v \mathrm{~cm}^{-1}\right): 3190(\mathrm{NH})$ and $1662(\mathrm{C}=\mathrm{O}) ;{ }^{1} \mathrm{H}-\mathrm{NMR}\left(\mathrm{DMSO}-d_{6}\right)$ $\delta$ ppm: 2.53, $2.66\left(2 \mathrm{~s}, 3 \mathrm{H}, \mathrm{CH}_{3}\right), 7.34,7.48(2 \mathrm{dd}, 1 \mathrm{H}, \mathrm{Ar}-\mathrm{H}$, $J=7.76,4.84 \mathrm{~Hz}), 7.70$ (d, 2H, Ar-H, $J=8.44 \mathrm{~Hz}), 7.85-8.01(\mathrm{~m}$, $2 \mathrm{H}, \mathrm{Ar}-\mathrm{H}), 8.10$ (d, 2H, Ar-H, $J=8.44 \mathrm{~Hz}), 8.15$ (d, 1H, Ar-H, $J=8.56 \mathrm{~Hz}), 8.38$ (s, 1H, Ar-H), 8.62 (d, $1 \mathrm{H}, \mathrm{Ar}-\mathrm{H}, J=4.80 \mathrm{~Hz})$, 8.88 (s, 1H, Ar-H), 12.09, $12.16\left(2 \mathrm{~s}, 1 \mathrm{H}, \mathrm{NH}, \mathrm{D}_{2} \mathrm{O}\right.$ exchangeable); ${ }^{13} \mathrm{C}-\mathrm{NMR}$ (DMSO- $\left.d_{6}\right) \delta$ ppm: 23.42, $23.49\left(\mathrm{CH}_{3}\right), 117.22$, $117.58,123.49,123.70,124.40,124.49,129.22,129.27,129.45$, $130.23,130.29,130.52,132.20,132.25,133.54,134.03,137.42$, $137.51,137.66,142.09,145.72,148.78,149.30,150.97,151.33$, 154.86, 155.08, 155.58, 156.54, 164.50, 170.52; Anal. Calcd for $\mathrm{C}_{19} \mathrm{H}_{15} \mathrm{BrN}_{4} \mathrm{O}: \mathrm{C}, 57.74 ; \mathrm{H}, 3.83 ; \mathrm{N}, 14.17$. Found: C, 58.08; H, $3.87 ; \mathrm{N}, 14.08$.

5-Bromo-2-(2-(4-chlorophenyl)-2-oxoethoxy)benzaldehyde 11 To a stirred mixture of 5-bromosalicylaldehyde 9 $(0.2 \mathrm{~g}, 1 \mathrm{mmol})$ and anhydrous potassium carbonate $(0.27 \mathrm{~g}$, $2 \mathrm{mmol})$ in absolute ethyl alcohol, a solution of 2-bromo-1(4-chlorophenyl)ethan-1-one $\mathbf{1 0}(0.23 \mathrm{~g}, 1 \mathrm{mmol})$ in absolute ethyl alcohol was added. The reaction mixture was stirred for $2 \mathrm{~h}$ at room temperature. The solid product was collected by filtration, washed with water and ether, and crystallized from isopropanol to afford white crystals of compound $\mathbf{1 1}$ (yield $55 \%), \mathrm{mp} 165-166^{\circ} \mathrm{C}$; IR $\left(\mathrm{KBr}, v \mathrm{~cm}^{-1}\right)$ : 1670, $1715(2 \mathrm{C}=\mathrm{O})$; ${ }^{1} \mathrm{H}-\mathrm{NMR}\left(\mathrm{DMSO}-d_{6}\right) \delta$ ppm: $5.83\left(2 \mathrm{~s}, 2 \mathrm{H},-\mathrm{OCH}_{2}-\right), 7.65(\mathrm{~d}$, $2 \mathrm{H}, \mathrm{Ar}-\mathrm{H}, J=8.48 \mathrm{~Hz}$ ), 7.76-7.79 (m, 2H, Ar-H), 8.02 (d, 2H, Ar-H, $J=8.72 \mathrm{~Hz}$ ), 8.07 (s, 1H, Ar-H), 10.41 (s, 1H, CHO); Anal. Calcd for $\mathrm{C}_{15} \mathrm{H}_{10} \mathrm{BrClO}_{3}$ : C, 50.95; H, 2.85. Found: C, 51.27; H, 2.79.

$N^{\prime}$-(5-Bromo-2-(2-(4-chlorophenyl)-2-oxoethoxy)benzylidene)-6-(4-bromophenyl)-2-methylnicotinohydrazide 12 Compound $11(0.35 \mathrm{~g}, 1 \mathrm{mmol})$ was added to a suspension of 6-(4-bromophenyl)-2-methylnicotinohydrazide $6 \quad(0.31 \mathrm{~g}$, $1 \mathrm{mmol})$ in absolute ethyl alcohol $(10 \mathrm{~mL})$ and a catalytic amount of glacial acetic acid. The reaction mixture was heated under reflux for $2 \mathrm{~h}$. The solid formed was filtered, washed with hot ethanol then crystallized from ethanol/DMF to furnish the target compound 12 with (yield $64 \%$ ), mp $236-238^{\circ} \mathrm{C}$; IR $\left(\mathrm{KBr}, v \mathrm{~cm}^{-1}\right): 3155(\mathrm{NH})$ and $1701(\mathrm{C}=\mathrm{O}) ;{ }^{1} \mathrm{H}-\mathrm{NMR}$ $\left(\mathrm{DMSO}-d_{6}\right) \delta$ ppm: 2.54, $2.67\left(2 \mathrm{~s}, 3 \mathrm{H}, \mathrm{CH}_{3}\right), 5.72,5.74(2 \mathrm{~s}$, $\left.2 \mathrm{H},-\mathrm{OCH}_{2}-\right), 7.02,7.12(2 \mathrm{~d}, 1 \mathrm{H}, \mathrm{Ar}-\mathrm{H}, J=8.92 \& 8.96 \mathrm{~Hz})$, 7.41, 7.53 (2 dd, 1H, Ar-H, J=8.92, 2.48 Hz), 7.53 (d, 2H, Ar-H, $J=8.44 \mathrm{~Hz}), 7.70$ (d, 2H, Ar-H, $J=8.48 \mathrm{~Hz}), 7.88-8.04$ (m, 5H, Ar-H), 8.10 (d, 2H, Ar-H, $J=8.48 \mathrm{~Hz}), 8.48,8.73(2 \mathrm{~s}, 1 \mathrm{H}$, Ar-H), 12.14 (s, 1H, NH, D 2 exchangeable); Anal. Calcd for $\mathrm{C}_{28} \mathrm{H}_{20} \mathrm{Br}_{2} \mathrm{ClN}_{3} \mathrm{O}_{3}$ : C, 52.41; H, 3.14; N, 6.55. Found: C, 52.18; H, 3.17; N, 6.69. 
4-(Morpholino/1-piperidino)benzaldehyde 15a, b

Compound $15 \mathbf{a}, \mathbf{b}$ was prepared according to reported procedure $^{41)}\left(\mathrm{mp} 66-69^{\circ} \mathrm{C}, 61-64^{\circ} \mathrm{C}\right.$, respectively).

General Procedure for Preparation of the Target Compounds 16a, b The appropriate aldehyde derivative 15a, b ( $1 \mathrm{mmol})$ was added to a solution of the 6-(4-bromophenyl)2-methylnicotinohydrazide $6(0.31 \mathrm{~g}, 1 \mathrm{mmol})$ in absolute ethyl alcohol $(10 \mathrm{~mL})$ and a catalytic amount of glacial acetic acid. The reaction mixture was heated under reflux for $4 \mathrm{~h}$. The formed precipitate was filtered off while hot, washed with methanol, and finally crystallized from ethanol/dioxane to give the target compounds $\mathbf{1 6 a}, \mathbf{b}$.

6-(4-Bromophenyl)-2-methyl- $N^{\prime}$-(4-morpholinobenzylidene)nicotinohydrazide (16a)

White crystals (yield $75 \%), \mathrm{mp}>300^{\circ} \mathrm{C}$; IR $\left(\mathrm{KBr}, v \mathrm{~cm}^{-1}\right)$ : $3185(\mathrm{NH})$ and $1658(\mathrm{C}=\mathrm{O})$; ${ }^{1} \mathrm{H}-\mathrm{NMR}\left(\mathrm{DMSO}-d_{6}\right) \delta \mathrm{ppm}$ : 2.52, $2.65\left(2 \mathrm{~s}, 3 \mathrm{H}, \mathrm{CH}_{3}\right), 3.11,3.21(2 \mathrm{t}, 4 \mathrm{H}$, morpholino- $\mathrm{H}$, $J=4.52 \mathrm{~Hz}), 3.67,3.73(2 \mathrm{t}, 4 \mathrm{H}$, morpholino-H, $J=4.68 \mathrm{~Hz})$, 6.87 (d, 1H, Ar-H, J=8.72 Hz), 7.00 (d, 1H, Ar-H, $J=8.80 \mathrm{~Hz}$ ), $7.26(\mathrm{~d}, \quad 0.5 \mathrm{H}, \quad \mathrm{Ar}-\mathrm{H}, J=8.68 \mathrm{~Hz}), 7.58(\mathrm{~d}, 1.5 \mathrm{H}, \quad \mathrm{Ar}-\mathrm{H}$, $J=8.72 \mathrm{~Hz}), 7.70$ (d, 2H, Ar-H, $J=8.52 \mathrm{~Hz}), 7.81$ (d, 0.5H, Ar-H, $J=8.04 \mathrm{~Hz}$ ), 7.90-7.99 (m, 2H, Ar-H), 8.09-8.13 (m, 2H, Ar-H), 8.19 (s, 0.5H, Ar-H), 11.69, 11.77 (2 s, 1H, NH, D 2 O exchangeable); Anal. Calcd for $\mathrm{C}_{24} \mathrm{H}_{23} \mathrm{BrN}_{4} \mathrm{O}_{2}$ : C, 60.13; H, 4.84; N, 11.69. Found: C, 59.88; H, 4.89; N, 11.74.

6-(4-Bromophenyl)-2-methyl- $N^{\prime}$-(4-(piperidin-1-yl)benzylidene) Nicotinohydrazide (16b)

White crystals (yield $80 \%$ ), mp $283-285^{\circ} \mathrm{C}$; IR (KBr, $\left.v \mathrm{~cm}^{-1}\right): 3170(\mathrm{NH})$ and $1661(\mathrm{C}=\mathrm{O}) ;{ }^{1} \mathrm{H}-\mathrm{NMR}\left(\mathrm{DMSO}-d_{6}\right) \delta$ ppm: 1.53-1.59 (m, 6H, piperidino-H), $2.64\left(\mathrm{~s}, 3 \mathrm{H}, \mathrm{CH}_{3}\right), 3.19$ (t, 4H, piperidino-H), $6.84(\mathrm{~d}, 1 \mathrm{H}, \mathrm{Ar}-\mathrm{H}, J=8.00 \mathrm{~Hz}), 6.97(\mathrm{~d}$, $1 \mathrm{H}, \mathrm{Ar}-\mathrm{H}, J=8.40 \mathrm{~Hz}), 7.21(\mathrm{~d}, 0.5 \mathrm{H}, \mathrm{Ar}-\mathrm{H}, J=8.28 \mathrm{~Hz}), 7.54$ (d, $1.5 \mathrm{H}, \mathrm{Ar}-\mathrm{H}, J=8.52 \mathrm{~Hz}), 7.71$ (d, 2H, Ar-H, $J=8.16 \mathrm{~Hz}$ ), $7.81(\mathrm{~d}, 0.5 \mathrm{H}, \mathrm{Ar}-\mathrm{H}, J=8.04 \mathrm{~Hz}), 7.90-7.97$ (m, 2H, Ar-H), 8.09-8.16 (m, 2.5H, Ar-H), 11.64, 11.73 (2 s, 1H, NH, D 2 exchangeable); Anal. Calcd for $\mathrm{C}_{25} \mathrm{H}_{25} \mathrm{BrN}_{4} \mathrm{O}$ : C, 62.90; H, 5.28; N, 11.74. Found: C, 62.69; H, 5.33; N, 11.81 .

Single Crystal X-Ray Crystallography The characterization of compounds $\mathbf{8 a}$ and $\mathbf{1 1}$ were also conducted by a single crystal X-ray structural analysis. The structures were solved with direct method and refined by SHELXTL. ${ }^{2,43)}$ The measurements were carried out on a Bruker SMART APEX IID8 Venture diffractometer. Crystallographic data of compounds 8a and $\mathbf{1 1}$ is deposited with the Cambridge Crystallographic Data Center with deposition number CCDC 1430062 and 1431357, respectively. The crystallographic structures, crystal packing, crystallographic data, refinement, selected geometric parameters and hydrogen-bond geometry of both compounds are illustrated in the Supplementary Materials.

Antimycobacterial Activity $M$. tuberculosis (RCMB 010126) strain was provided from culture collection of the RCMB, Al-Azhar University, Cairo, Egypt. Isoniazide and pyrazinamide were used as reference drugs. Antimycobacterial activity of the synthesized compounds was evaluated using the microplate Alamar blue assay (MABA) ${ }^{36)}$ which was performed in black, clear-bottomed, 96-well microplates (in order to minimize background effect). Outer perimeter wells were filled with sterile water to prevent dehydration in experimental wells. Initial compounds dilutions were prepared in dimethyl sulfoxide and subsequent twofold dilutions were performed in the microplates. $0.1 \mathrm{~mL}$ of $10^{5} \mathrm{CFU} / \mathrm{mL}$ M. tuberculosis in- oculum was added to wells, additional control wells consisted of bacteria only (B). Plates were incubated at $37^{\circ} \mathrm{C}$. Starting at day 4 of incubation, $20 \mu \mathrm{L}$ of alamarBlue solution (Alamar Biosciences/Accumed, Westlake, OH, U.S.A.) and $12.5 \mu \mathrm{L} 1$ of $20 \%$ Tween 80 were added added to the entire plate. Plates were then incubated at $37^{\circ} \mathrm{C}$, and results were recorded at $24 \mathrm{~h}$ post-reagent addition at $590 \mathrm{~nm}$. Percent inhibition was defined as: $1-$ (mean of test well/mean of B wells) $\times 100$. Visual MICs were defined as the lowest concentration of drug that prevented a color change.

Antimicrobial Activity All strains were provided from culture collection of the RCMB, Al-Azhar University, Cairo, Egypt. Antibacterial and antifungal activities were expressed as the diameter of inhibition zones; Agar well diffusion method was used as described earlier. ${ }^{44,45}$ Holes ( $1 \mathrm{~cm}$ diameter) were digger in the agar using sterile cork borer in sterile malt agar plates for fungi and sterile nutrient agar plates for bacteria, which had previously been uniformly seeded with tested microorganisms. The holes were filled by fungal filtrates $(100 \mu \mathrm{L})$. Plates were left in a cooled incubator at $4^{\circ} \mathrm{C}$ for one hour for diffusion and then incubated at $37^{\circ} \mathrm{C}$ for tested bacteria and $28^{\circ} \mathrm{C}$ for tested fungi. Inhibition zones developed due to active antimicrobial metabolites were measured after $24 \mathrm{~h}$ of incubation for bacteria and $48 \mathrm{~h}$ of incubation for fungi. Amphotericin B and ciprofloxacin were used as antifungal and antibacterial positive control, respectively. The experiment was performed in triplicate and the average zone of inhibition was calculated.

MIC

MIC was performed by a serial dilution technique described by Irobi et al., ${ }^{46)}$ starting with 100 -mmol concentration of all compounds dissolved in $1 \mathrm{~mL}$ DMSO and then reduced by successive twofold dilutions of stock solution using a calibrated micropipette. Amphotericin B and ciprofloxacin were used as the reference compounds for fungi and bacteria; respectively. The final solutions concentrations were $125,62.50,31.25,15.63,7.81,3.90,1.95,0.98,0.49,0.24$ and $0.12 \mu \mathrm{mol} / \mathrm{mL}$. The microtiter plates were incubated at $37^{\circ} \mathrm{C}$ for tested bacteria and $28^{\circ} \mathrm{C}$ for tested fungi and were readied using microplate reader after $24 \mathrm{~h}$ for bacteria and after $48 \mathrm{~h}$ for fungi. In each case, triplicate tests were performed and the average was taken as final reading. MIC was expressed as the lowest concentration inhibiting test organism's growth.

Cytotoxicity against WI-38 WI-38 cells (normal breast cells), were obtained from American Type Culture Collection. The cells were propagated in Dulbecco's modified Eagle's medium (DMEM) supplemented with 10\% heat-inactivated fetal bovine serum (FBS) (Hyclone), $10 \mathrm{ug} / \mathrm{mL}$ of insulin (Sigma), and $1 \%$ penicillin-streptomycin. All of the other chemicals and reagents were from Sigma, or Invitrogen. Cytotoxicity was determined using MTT assay following a reported procedure. ${ }^{47)} \mathrm{The} \mathrm{IC}_{50}$ was estimated from graphic plots of the dose response curve for each conc. using Graphpad Prism software (San Diego, CA, U.S.A.). The data presented are the mean of at least three separate experiments.

Acknowledgment The authors would like to extend their sincere appreciation to the Deanship of Scientific Research at King Saud University for its funding of this research through the Research Group Project No. RG-1436-038. 
Conflict of Interest The authors declare no conflict of interest.

Supplementary Materials The online version of this article contains supplementary materials.

\section{REFERENCES}

1) “Antimicrobial resistance, Fact sheet $N^{\circ} 194 . "$ : 〈www.who.int/ mediacentre/factsheets/fs194/en/s, Updated April 2015.

2) Viswanathan VK. Off-label abuse of antibiotics by bacteria. Gut Microbes, 5, 3-4 (2014).

3) Gould IM, Bal AM. New antibiotic agents in the pipeline and how they can overcome microbial resistance. Virulence, 4, 185-191 (2013).

4) Sengupta S, Chattopadhyay MK, Grossart HP. The multifaceted roles of antibiotics and antibiotic resistance in nature. Front Microbiol., 4, 47 (2013).

5) Read AF, Woods RJ. Antibiotic resistance management. Evol. Med. Public Health, 2014, 147 (2014).

6) Lushniak BD. Antibiotic resistance: a public health crisis. Public Health Rep., 129, 314-316 (2014).

7) Gross M. Antibiotics in crisis. Curr. Biol., 23, R1063-R1065 (2013).

8) Bayrak H, Demirbas A, Demirbas N, Karaoglu SA. Synthesis of some new 1,2,4-triazoles starting from isonicotinic acid hydrazide and evaluation of their antimicrobial activities. Eur. J. Med. Chem., 44, 4362-4366 (2009).

9) Deutscher M, Friedman C. Management of antimicrobials Infectious Diseases: Impact of Antibiotics. (Mainous AG, Pomeroy C eds.) Springer Humana Press, New York, pp. 1-6 (2010).

10) World Health Organization. "Global tuberculosis report 2014." 〈http://www.who.int/tb/publications/global report〉, accessed 27 October, 2015

11) Eker B, Ortmann J, Migliori GB, Sotgiu G, Muetterlein R, Centis R, Hoffmann H, Kirsten D, Schaberg T, Ruesch-Gerdes S, Lange C. Multidrug- and extensively drug-resistant tuberculosis, Germany. Emerg. Infect. Dis., 14, 1700-1706 (2008).

12) Falzon D, Gandhi N, Migliori GB, Sotgiu G, Cox H, Holtz TH, Hollm-Delgado MG, Keshavjee S, DeRiemer K, Centis R, D'Ambrosio L, Lange C, Bauer M, Menzies D. Resistance to fluoroquinolones and second-line injectable drugs: impact on multidrug-resistant TB outcomes. Eur. Respir. J., 42, 156-168 (2013).

13) "Tuberculosis, Fact sheet $\mathrm{N}^{\circ} 104 . "$ 〈WWw.who.int/mediacentre/ factsheets/fs104/en/> (2015).

14) Jiao WW, Mokrousov I, Sun GZ, Li M, Liu JW, Narvskaya O, Shen AD. Molecular characteristics of rifampin and isoniazid resistant Mycobacterium tuberculosis strains from Beijing, China. Chin. Med. J., 120, 814-819 (2007).

15) Bacelar AH, Carvalho MA, Proenca MF. Synthesis and in vitro evaluation of substituted pyrimido[5,4-d]pyrimidines as a novel class of anti-Mycobacterium tuberculosis agents. Eur. J. Med. Chem., 45, 3234-3239 (2010).

16) Zhao Y, Xu S, Wang L, Chin DP, Wang S, Jiang G, Xia H, Zhou Y, Li Q, Ou X, Pang Y, Song Y, Zhao B, Zhang H, He G, Guo J, Wang Y. National survey of drug-resistant tuberculosis in China. N. Engl. J. Med., 366, 2161-2170 (2012).

17) Janin YL. Antituberculosis drugs: Ten years of research. Bioorg. Med. Chem., 15, 2479-2513 (2007).

18) Navarrete-Vazquez G, Molina-Salinas GM, Duarte-Fajardo ZV, Vargas-Villarreal J, Estrada-Soto S, Gonzalez-Salazar F, Hernández-Nùñez E, Said-Fernandez S. Synthesis and antimycobacterial activity of 4-(5-substituted-1,3,4-oxadiazol-2-yl)pyridines. Bioorg. Med. Chem., 15, 5502-5508 (2007).

19) Bayrak H, Demirbas A, Demirbas N, Karaoglu SA. Synthesis of some new 1,2,4-triazoles starting from isonicotinic acid hydrazide and evaluation of their antimicrobial activities. Eur. J. Med. Chem.,
44, 4362-4366 (2009).

20) Rollas S, Kucukguzel G. Biological activities of hydrazine derivatives. Molecules, 12, 1910-1939 (2007).

21) Rane RA, Telvekar VN. Synthesis and evaluation of novel chloropyrrole molecules designed by molecular hybridization of common pharmacophores as potential antimicrobial agents. Bioorg. Med. Chem. Lett., 20, 5681-5685 (2010).

22) Joshi SD, Vagdevi HM, Vaidya VP, Gadaginamath GS. Synthesis of new 4-pyrrol-1-yl benzoic acid hydrazide analogs and some derived oxadiazole, triazole and pyrrole ring systems: a novel class of potential antibacterial and antitubercular agents. Eur. J. Med. Chem., 43, 1989-1996 (2008).

23) Sriram D, Yogeeswari P, Madhu K. Synthesis and in vitro antitubercular activity of some 1-[(4-sub)phenyl)-3-(4-\{1-((pyridine-4carbonyl)hydrazono)ethyl\}phenyl)thiourea. Bioorg. Med. Chem. Lett., 16, 876-878 (2006).

24) Nayyar A, Monga V, Malde AK, Coutinho E, Jain R. Synthesis, anti-tuberculosis activity and 3D-QSAR study of 4-(adamantan1-yl)-2-substituted quinolines. Bioorg. Med. Chem., 15, 626-640 (2007).

25) Nayyar A, Jain R. Recent advances in new structural classes of anti-tuberculosis agents. Curr. Med. Chem., 12, 1873-1886 (2005).

26) Fu LM, Shinnick TM. Genome-wide exploration of the drug action of capreomycin on Mycobacterium tuberculosis using Affymetrix oligonucleotide Gene Chips. J. Infect., 54, 277-284 (2007).

27) Narang R, Narasimhan B, Sharma S, Sriram D, Yogeeswari P, De Clercq E, Pannecouque C, Balzarini J. Synthesis, antimycobacterial, antiviral, antimicrobial activities, and QSAR studies of nicotinic acid benzylidene hydrazide derivatives. Med. Chem. Res., 21, $1557-1576$ (2012).

28) Sinha N, Jain S, Tilekar A, Upadhayaya RS, Kishore N, Jana GH, Arora SK. Synthesis of isonicotinic acid $N$-arylidene- $N$-2-oxo-2-(4aryl-piperazin-1-yl)ethyl-hydrazides as antituberculosis agents. Bioorg. Med. Chem. Lett., 15, 1573-1576 (2005).

29) Kumar D, Khare G, Beena B, Kidwai S, Tyagi AK, Singh R, Rawat DS. Novel isoniazid-amidoether derivatives: synthesis, characterization and antimycobacterial activity evaluation. Med. Chem. Commun., 6, 131-137 (2015).

30) Eldehna WM, Fares M, Abdel-Aziz MM, Abdel-Aziz HA. Design, synthesis and antitubercular activity of certain nicotinic acid hydrazides. Molecules, 20, 8800-8815 (2015).

31) Abdel-Aziz HA, Eldehna WM, Fares M, Al-Rashood STA, A1Rashood KA, Abdel-Aziz MM, Soliman DH. Synthesis, biological evaluation and 2D-QSAR study of halophenyl bis-hydrazones as antimicrobial and antitubercular agents. Int. J. Mol. Sci., 16, 8719$8743(2015)$

32) Abdel-Aziz HA, Eldehna WM, Fares M, Elsaman T, Abdel-Aziz MM, Soliman DH. Synthesis, in vitro and in silico studies of some novel 5-nitrofuran-2-yl hydrazones as antimicrobial and antitubercular Agents. Biol. Pharm. Bull., 38, 1617-1630 (2015).

33) Abdel-Aziz HA, Ghabbour HA, Eldehna WM, Qabeel MM, Fun $\mathrm{H}-\mathrm{K}$. Synthesis, crystal structure and biological activity of cis/trans amide rotomers of $(Z)-N^{\prime}$-(2-oxoindolin-3-ylidene)formohydrazide. J. Chem., 2014, 760434 (2014).

34) Eldehna WM, Fares M, Ceruso M, Ghabbour HA, Abou-Seri SM, Abdel-Aziz HA, Abou El Ella DA, Supuran CT. Amido/ureidosubstituted benzenesulfonamides-isatin conjugates as low nanomolar/ subnanomolar inhibitors of the tumor-associated carbonic anhydrase isoform XII. Eur. J. Med. Chem., 110, 259-266 (2016).

35) Eldehna WM, Almahli H, Al-Ansary GH, Ghabbour HA, Aly MH, Ismael OE, Al-Dhfyan A, Abdel-Aziz HA. Synthesis and in vitro anti-proliferative activity of some novel isatins conjugated with quinazoline/phthalazine hydrazines against triple-negative breast cancer MDA-MB-231 cells as apoptosis-inducing agents. J. Enzyme Inhib. Med. Chem., 32, 600-613 (2017).

36) Collins L, Franzblau SG. Microplate alamar blue assay versus 
BACTEC 460 system for high-throughput screening of compounds against Mycobacterium tuberculosis and Mycobacterium avium. Antimicrob. Agents Chemother., 41, 1004-1009 (1997).

37) Mosmann T. Rapid colorimetric assay for cellular growth and survival: application to proliferation and cytotoxicity assays. J. Immunol. Methods, 65, 55-63 (1983).

38) Lin Y-I, Lang SA. New synthesis of isoxazoles and isothiazoles. A convenient synthesis of thioenaminones from enaminones. J. Org. Chem., 45, 4857-4860 (1980).

39) Eldehna WM, Altoukhy A, Mahrous H, Abdel-Aziz HA. Design, synthesis and QSAR study of certain isatin-pyridine hybrids as potential anti-proliferative agents. Eur. J. Med. Chem., 90, 684-694 (2015).

40) Jagath Reddy G, Latha D, Thirupathaiah C, Rao KS. A facile synthesis of 2,3-disubstituted-6-arylpyridines from enaminones using montmorillonite $\mathrm{K} 10$ as solid acid support. Tetrahedron Lett., 46, 301-302 (2005)

41) Gale DJ, Wilshire JFK. The preparation of some polymethine Astrazon dyes. Aust. J. Chem., 23, 1063-1068 (1970).

42) Sheldrick GM. A short history of SHELX. Acta Crystallogr. A, 64, 112-122 (2008)

43) Abdel-Aziz HA, Ghabbour HA, Eldehna WM, Al-Rashood SA, Al-Rashood KA, Fun HK, Al-Tahhan M, Al-Dhfyan A. 2-((Benz- imidazol-2-yl)thio)-1-arylethan-1-ones: Synthesis, crystal study and cancer stem cells CD133 targeting potential. Eur. J. Med. Chem., 104, 1-10 (2015).

44) Fares M, Said MA, Alsherbiny MA, Eladwy RA, Almahli H, Abdel-Aziz MM, Ghabbour HA, Eldehna WM, Abdel-Aziz HA. Synthesis, Biological Evaluation and Molecular Docking of Certain Sulfones as Potential Nonazole Antifungal Agents. Molecules, 21, E114 (2016)

45) Ibrahim HS, Eldehna WM, Abdel-Aziz HA, Elaasser MM, AbdelAziz MM. Improvement of antibacterial activity of some sulfa drugs through linkage to certain phthalazin-1 $(2 H)$-one scaffolds. Eur. J. Med. Chem., 85, 480-486 (2014).

46) Irobi ON, Moo-Young M, Anderson WA. Antimicrobial activity of annatto (Bixa orellana) extract. Pharm. Biol., 34, 87-90 (1996).

47) Eldehna WM, Abo-Ashour MF, Nocentini A, Gratteri P, Eissa IH, Fares M, Ismael OE, Ghabbour HA, Elaasser MM, Abdel-Aziz HA, Supuran CT. Novel 4/3-((4-oxo-5-(2-oxoindolin-3-ylidene)thiazolidin-2-ylidene)amino) benzenesulfonamides: Synthesis, carbonic anhydrase inhibitory activity, anticancer activity and molecular modelling studies. Eur. J. Med. Chem., 139, 250-262 (2017).

48) "Drug-likeness and molecular property prediction.": 〈http://www. molsoft.com/mprop/s, accessed on 19 Nov. 2016. 